\title{
Production and Technology of Iron and Steel in Japan during 1988
}

\section{Shigeo HOSOKI}

Chief Secretary, The Joint Research Society, The Iron and Steel Institute of Japan, Otemachi, Chiyoda-ku, Tokyo, 100 Japan.

KEY WORDS: steel industry; technology progress; capital investment; rationalization; productivity; economic situation; raw materials; energy; foreign trade; cast reduction.

\section{Economical Situation Surrounding the Iron and Steel Industry}

The economy in our country has undergone a marked impact of the rapid appreciation of Yen's value after the Plaza Mutual Agreement reached in the fall of 1985. This economy, however, through bottoming out at the end of 1986, has been showing a rapid recovery since the summer of 1987 thanks to the buoyancy of domestic demand and the penetrating effect of the emergency economical policies enacted in May, 1987. Thus, the economy is entering a phase of business rise led by the domestic demand at present time. The economic growth in 1987 fiscal year (F.Y.) achieved a real growth of $4.9 \%$ (domestic demand percentage contribution: $6.0 \%$ and external one: $-1.0 \%$ ) and that in 1988 F.Y. will most likely to considerably exceed the Government economic forecast (real growth $3.8 \%$ ).

When the economy is viewed from the aspect of final demand, consumer buying has been favorably developing due to price stability, income increase accompanied by business upturn, and demand increase in housing-related products supported by the booming days of housing. In the investment allied business, showing an upward trend and bottom falling out were the public investment using as a lever the emergency economic policies determined on last May, and housing investment supported by the housing construction promotion tax system and low interest. After that, however, a shadow has partly been cast on their impetus. Private equipment investment centered around manufacturers, on the other hand, has drastically increased due to an increase in equipment utilization rate and an improvement in company profits backed by the buoyancy of consumer expenditure, public investment, and housing investment.

Small and intermediate sized businesses as well are heading into a recovery under the economic climate described above; however, there are some businesses among export-oriented industries and company-town industries that still remain sluggish. As regards international relation, the export surplus of our country is tending toward reducing; nevertheless, the surplus is still so large in scale that it amounts to a colossal sum, further steady corrections being required to be made.
The present situation of the steel industry, when looked at under these economic environment, is that the production has reduced since the last half of 1985 F.Y. because of the fall of domestic consumption due to the private equipment investment which is held in check, sharp rise in Yen's value, and the stagnation of the activities in demand industries, and also because of the fall of export due to the voluntary restraint of export to the USA and abrupt rise in Yen's value. Entering upon the second quarter of the 1987 F.Y., however, business took a turn for the better because of an increase in the construction sector stimulated by the home market expansion policy by the Government and advance of inventory adjustment. The production of crude steel, showing progress as shown in Table 1 , stood above the level of a year earlier in July, 1987 after the lapse of two years and a month. Since that time, the production has been being kept at a level which is above that of the previous year, reaching 118.8 million $t$ in 1987 F.Y. which is above the previous year's level by $5.7 \%$. The production in the first half of $1988 \mathrm{~F} . \mathrm{Y}$. has been keeping firm, amounting to 52.24 million $t$ (anticipated results), $7.2 \%$ higher than in the comparable period of the year before, and will achieve about 105 million $\mathrm{t}$ in 1988, being expected to go above the last year level by $6.9 \%$.

Steel exports have been trending downward since the fall of 1985 because of a decrease in new order implementation (especially in electric furnace steels) due to voluntary restraint of export to the USA and sudden rise in Yen's value. The exports in 1987 F.Y. showed a decrease on the level of a year ago by 4.64 million $t, 15.3 \%$. When exports are classified by the export destination, that for China decreased by 3.4 million $t$, and that in the first half of 1988 F.Y. was 1.21 million $t$ less than in the parallel period last year, being $9.4 \%$ reduction. Imports, on the other hand, has largely increased due to high value of the Yen. Imports of ordinary carbon steels in 1987 F.Y. increased by 1.55 million $t, 53.3 \%$ over the previous year. When classified by the sources of imports, conspicuous was an increase of imports from Korea, amounting to 600 thousand $t$, and from other countries such as Turkey, Indonesia, and Rumania. Imports in the first half of $1988 \mathrm{~F} . \mathrm{Y}$. increased by 1.53 million $t, 81.0 \%$ from the equivalent period of last 


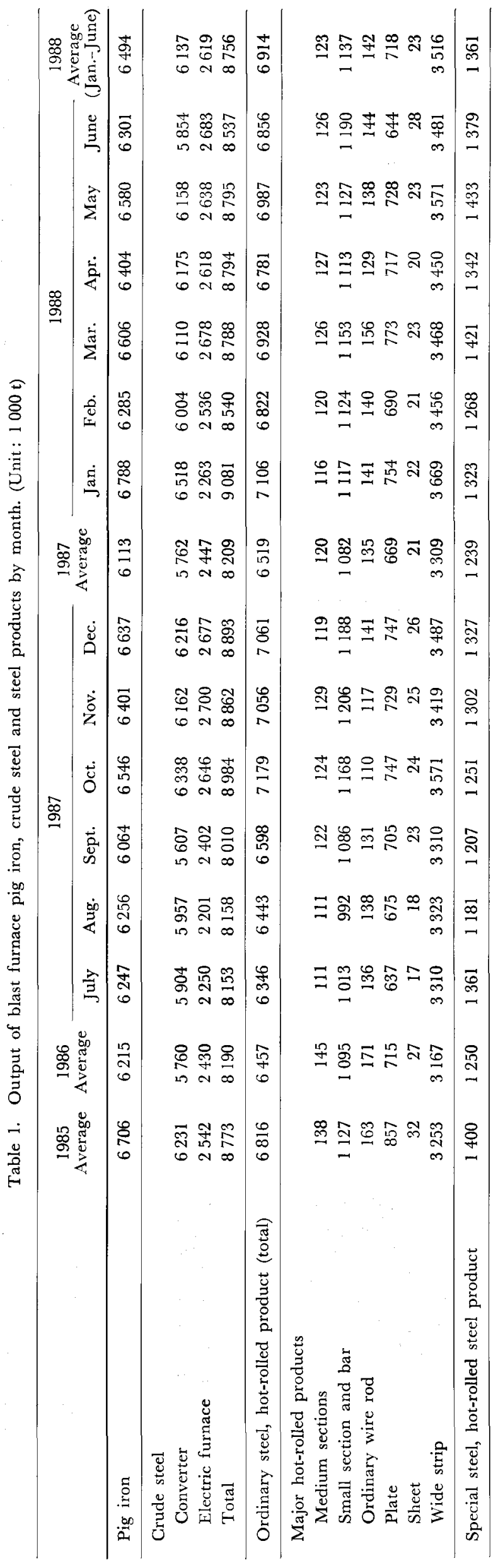

year. When classified by the sources of imports, those from Korea and Brazil increased by 660 and 270 thousand $t$, respectively.

Placed in the situation mentioned above, the steel market which had been following a continuing downward trend since the latter half of 1985 F.Y. took a turn for the rapid rise as to products principally around merchant bars and $\mathrm{H}$-shape sections during the period of about three months from July, 1987, backed by the positive tone of domestic demand and a reduction in merchant stock due to the summer time reduction of production by electric-furnaces steel manufacturers. The market conditions of merchant bars and H-shape sections, after going down from the end of 1987 below the level directly before the appreciation of Yen's value in the fall of 1985 F.Y., has recovered since last May, running at a stabilized level.

The number of employees in the steel industry has been trending downward in recent years, which has been coped with by the restriction of recruitment and the shifting of key workers into associated companies. As has been stated in the interim report prepared by the Consultative Committee on Basic Material Industry of Ministry of International Trade and Industry, it is considered that the crude steel production in our country will unavoidably tread downward trend when viewed from a long-and-medium-range outlook. In this connection, integrated iron and steel manufacturers have further been pushing forward with the streamlining of management such as slimming of work force, suspension, discarding, and concentration of production facilities, and expansion of new business lines.

Regarding the behavior of equipment investment, the equipment investment plan by the steel industry for the 1988 F.Y. appropriates a sum of 501.9 billion yen, meaning an improvement by 20 billion yen, $4.2 \%$ over the previous year. The equipment investment plan for the 1988 F.Y. are principally aimed at investments associated with streamlining, laborsaving, equipment renewal, and energy-saving.

As regards the tendency of demand and supply of raw materials, iron ore consumption in our country for the 1987 F.Y. has increased by 110.69 million $t$, $-5.2 \%$ above the last-year level-because of an increase in pig iron production above that last year. Regarding ore supply, mostly dependent on overseas ore, the imported iron ore in 1987 F.Y. reached 118.06 million $\mathrm{t}$ (wet base), resulting in an increase by $6.4 \%$ over last year. Major ore exporting countries are Australia, Brazil, and India. The quantity of ore imported from these three countries accounts for $82.3 \%$ of all the ore imported by our country in 1987 F.Y.

With regard to coking coal, the consumption of such coal for ironmaking in our country in 1987 F.Y. is 62.76 million $t$, resulting in an increase as is the case with iron ore, by $3.2 \%$ over the year-earlier level. As regards the quantity of coal supply in 1987 F.Y., domestic coal amounted to about 800 thousand $t$, about $62 \%$ under last year, and imported coal 619.61 million t, $6 \%$ above 1986 F.Y. Major 
coal exporting countries are Australia, the USA, and Canada, and the coal quantity imported from these three countries accounts for $82.4 \%$ of the total coal imported to our country.

\section{Technology and Equipment}

\subsection{Ironmaking}

Supply and demand of steel products have taken a favorable turn due to the effect of home market expansion policy and that of the rationalization brought about by the medium-term streamlining-scheme of various steelmaking companies. Thus, the blast furnace production increased with an increase in crude steel production since the latter half of 1987 F.Y.

With the implementation of the medium-termprojects of various companies, the number of instalied blast furnaces has been reduced by three, ending in the total of 48 units (as of the end of June, 1988).

Operating blast furnaces in 1988 is 36 units, being the same as those in 1987 including blowing-in and blowing-out of various blast furnaces: namely, in 1988, Kakogawa No. 1 BF $\left(4550 \mathrm{~m}^{3}\right)$ of Kobe Steel, Ltd. was blown-in in January, and No. 3 BF (4 500 $\mathrm{m}^{3}$ ) blown-out in February; Wakayama No. 5 BF $\left(2700 \mathrm{~m}^{3}\right.$ ) of Sumitomo Metal Industries, Ltd. blownin in February and Funamachi No. 2 BF of Nakayama Steel Works, Ltd. blown-out in March and blown-in in May; Kure No. 2 BF $\left(1650 \mathrm{~m}^{3}\right)$ of Nisshin Steel Co., Ltd. blown-out in April (under repair) (as of the end of June 1988).

Table 2 provides the results of blast furnace operation records. Productivity coefficient kept creeping up from April 1987 until it reached $1.88 \mathrm{t} / \mathrm{m}^{3} \cdot \mathrm{d}$ in November 1987 , being $1.89 \mathrm{t} / \mathrm{m}^{3} \cdot \mathrm{d}$, an average over the period from January to June 1988. Fuel ratio is progressing with a value of about $510 \mathrm{~kg} / \mathrm{t}$ this year as well.

Injection of pulverized non-coking coal, the rate of which had been increasing due to the advantages of stabilization of furnace condition, economy, and natural resources saving measures, has turned to slightly downward this year, being $28 \mathrm{~kg} / \mathrm{t}$ as an average over the period from January to June 1988.

The blast furnace operation in which Artificial Intelligence (A.I.) is adopted has been applied to or under contemplation by No. 5 BF of Fukuyama Works, NKK Corp., No. 4 BF of Kimitsu Works and No. 2 BF of Oita Works, Nippon Steel Corp., No. 4 BF of Mizushima Works, Kawasaki Steel Corp., No. 1 BF of Kashima Steel Works, Sumitomo Metal Industries, Ltd., and No. 1 BF of Kakogawa Works, Kobe Steel, Ltd.

No. 5 BF of Fukuyama Works, NKK Corp., has achicved low-silicon opcration at a level of Si $0.1 \%$ for 3 months in succession since January 1988 by means of A.I. control.

In the area of raw materials for blast furnaces, a production method of "HPS" (NKK), agglomerate for blast furnaces, in which the features of both manufacturing processes of conventional sinter ore and pellets are incorporated has been developed. In the field of blast furnace operation methods, on the other hand, new technologies associated with the manufacturing methods and operation stated in the following have been brought forth, with much expectation left for their achievement in the future. These new technologies include a center-charging method of coke (No. 2 BF of Kakogawa Works, Kobe Steel, Ltd.) in which coke for filling the furnace center is charged in the center part of the blast furnace throat, enabling easy control of gas and liquid permeability, and a system of microcomputer-aided automatic control of hot stoves which are potentially effective in energy-saving.

\subsection{Steelmaking}

Recent trend in steelmaking operation is characterized by the improvements in crude steel output/ hour and ratios of continuous casting as given in Table 3, "Operation performance of converters" and Table 4, "Operation performance of electric furnaces".

Every steelmaking companies are putting forward the cutback of production cost and advancement of quality of products. In the steclmaking sector, efforts have been directed to the expansion of hot-metal pretreatment, increase of secondary refining, and energy saving for efficient production of high quality and high purity stecl. Fig. 1 shows changes of durable times of converter furnace lining. The elongation of the recent furnace lining life is much indebted to the improvement of the materials of refractories and that of operational technology. The increase in the application of magnesia carbon brick has enabled the life of refractories for lining of converters to extend about twice as long. During about 10 months campaign of a top-bottom-blowing converter at Kimitsu Works of Nippon Steel Corp. from August 1987 to June 1988, accomplished life was a record of 5800 continuous tapping times without any intermediate shutdown for refractory repair, which is the world-
0

983

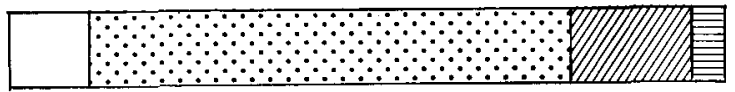

1984

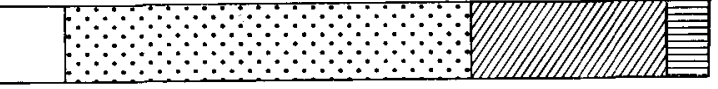

1985

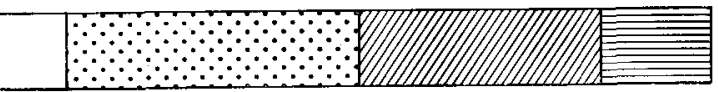

1986

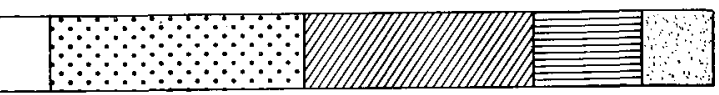

1987

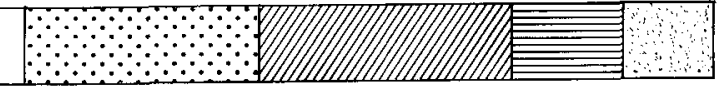

Fig. 1. Changes of durable times of converter furnace lining.

Source: Tekko-kai, (1988), May. 

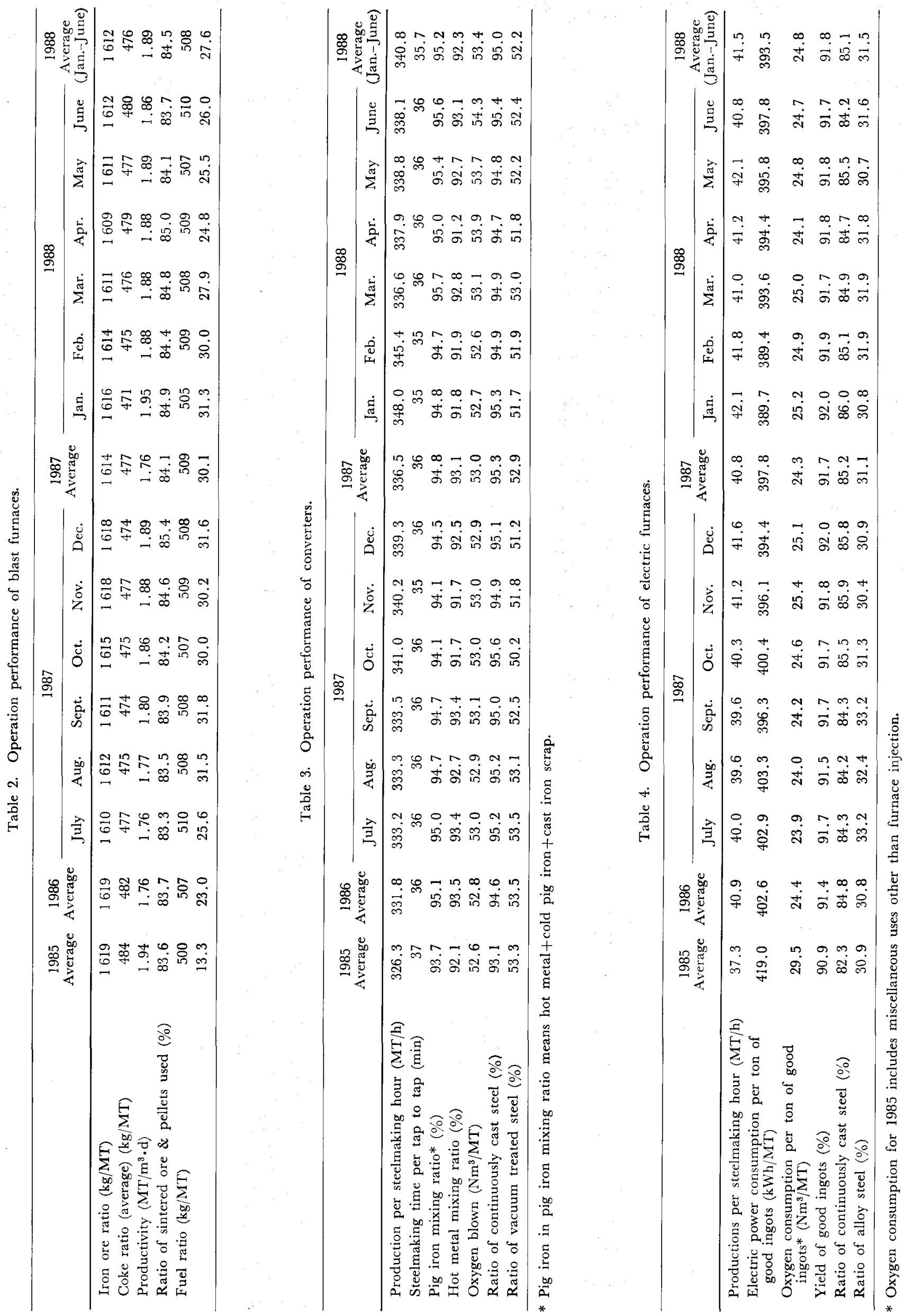
wide record of the longest lining life of such converter. With electric furnaces, the introduction of direct current furnace is now underway. Compared with conventional $\mathrm{AC}$ elcctric furnaces, $\mathrm{DG}$ electric furnaces have merits of (1) reduction in specific electrode consumption, (2) reduction in specific power consumption, (3) curtailment of melting time, and (4) decrease of specific consumption of furnace lining repair materials. Toyohashi Works of Topy Industries, Ltd. was the first in Japan to introduce an DC electric furnace $(30 \mathrm{t})$, bringing it into the line from January 1988 with the merits of cost down being achieved. This has spurred various manufacturers to becoming enthusiastic for introduction of this type of furnace.

Tokyo Steel Manufacturing Co., Ltd. has determined to construct a new DC electric furnace of an effective capacity of $130 t$, the largest one in the world, which is scheduled to be brought to operation in September 1989. As shown in Table 5, secondary refining treatment ratio is still continuing to move upwards, reaching as high as 71.7 and $53.4 \%$ with converter steels and with electric furnace steels, respectively, showing that the needs for higher grade steels have yearly been increasing.

\subsection{Continuous Casting and Blooming-Slabbing}

Fig. 2 shows the change of the ratio of continuous casting production in our country. When the ratio of continuous casting in 1987 F.Y. is classified by steel grades, that of ordinary carbon steel with a production of 80.54 million $t$ reaches $97.3 \%$, a rise of 0.4 points over the previous year, while that of alloy steels with a production of 14.47 million $t, 80.6 \%$, 0.1 points under last year.

With the aim of achieving process-saving and energy-saving, the development of thin slab continuous casting technology has been promoted. Jointly with Hitachi Ltd., Chiba Works of Kawasaki Steel Corp. conducted experiments on thin-slab continuous casting, having been successful for the first time in the world in cold rolling of hot rolled coils produced from such continuously cast thin slabs. These starting materials were produced by the process in which using an experimental equipment of a twin-belt type thin slab continuous caster, slabs of a thickness of $30 \mathrm{~mm}$ and a width of $800 \mathrm{~mm}$ were cast at a casting speed of $10 \mathrm{~m} / \mathrm{min}$, coiled up as hot into a coil of 12 to $16 \mathrm{t}$ in unit weight, and then directly hot rolled without reheating. The products, presently being produced by this method, are cold-rolled steels for general use; however, casting of a variety of steel grades for future development are now under contemplation. Sagamihara Works of Nippon Metal Industry Cio.,
Ltd. has commenced experiments of producing strips with a thickness of 2 to $4 \mathrm{~mm}$ and a width of $600 \mathrm{~mm}$ using an experimental equipment for making thin strips which are produced by rapid solidification of molten stainless steel between two rolls.

Among all the electric furnace steel manufacturers, Topy Industries, Ltd. took the lead in the introduction of an in-tundish molten steel heating device which was developed jointly with Sumitomo Heavy Industries, Ltd. This device is designed to hold constant the temperature of molten steel in the tundish and improve quality of the internal part of the cast slab by float-out inclusion from molten steel using stirring method.

\subsection{Rolling and Surface Treatment}

In the field of plate and sheet rolling, the production has increased over that in 1986. In the sector of production of hot rolled plates and sheets, under the above situation, it tended that efforts were exerted at development of new products rather than at installation of new facilities. In the sector of cold rolled sheets and surface treated sheets, numerous installation of new equipment and remodeling aimed at improvement of productivity and quality have been executed with growing demand in its background.

As regards the equipment for steel plates, stainless steel plate manufacturing equipment has been installed at Fukuyama Works of NKK Corp. and edge miller equipment at Mizushima Works of Kawasaki Steel Corp. In view of technology, manufacturing

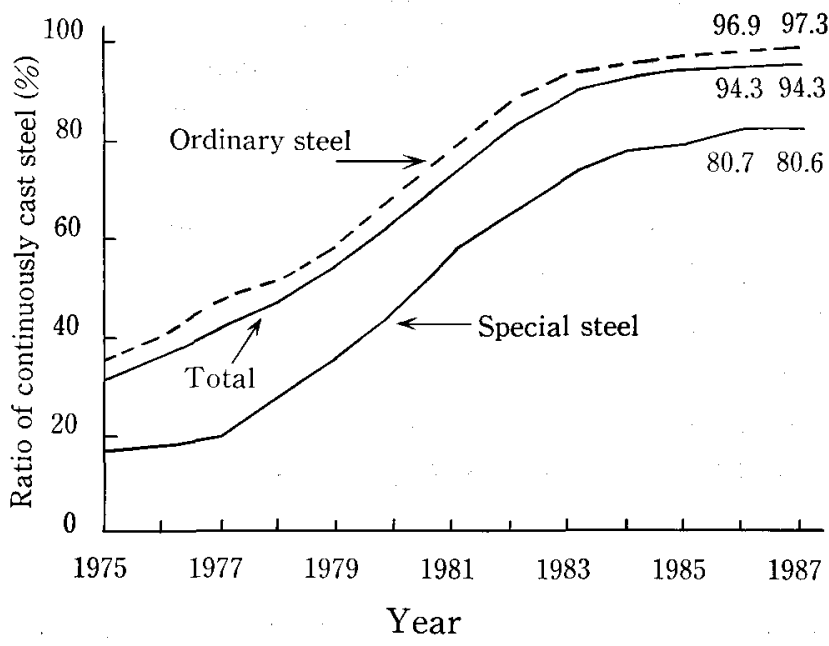

Ratio of continuously cast steel $(\%)=$ Continuous cast material/Total hot rolled material

Fig. 2. The change of the ratio of continuous casting production.

Source: Tekko-kai, (1988), No. 5 (May).

Table 5. Secondary refined steel ratio and its trend. (\%)

\begin{tabular}{|c|c|c|c|c|c|}
\hline & & 1984 & 1985 & 1986 & 1987 \\
\hline \multirow{2}{*}{ Converter } & Total secondary refined steel & - & 65.9 & 70.4 & 71.7 \\
\hline & Vacuum treated steel (out of the above figure) & 50.0 & 53.3 & 53.5 & 52.9 \\
\hline Electric furnace & Total secondary refined steel & 42.5 & 49.1 & 51.4 & 53.4 \\
\hline
\end{tabular}

Source: Tekko-kai, (1988), No. 5 (May). 
techniques that have been developed include: manufacturing techniques of taper plates in the transverse direction and fire-resistant steels for construction of steel structure by Nippon Steel Corp., manufacturing techniques of high-strength stainless steel plate and leveling techniques in operating a hot leveler for plates of a new type by Fukuyama Works of NKK Corp., manufacturing techniques of ultra-heavy plates for skyscrapers and manufacturing techniques of high strength steels for large-heat-input welding by Sumitomo Metal Industries, Ltd., direct gamma-ray thickness gage for a plate finishing mill by Mizushima Works of Kawasaki Steel Corp., and manufacturing techniques of nickel-clad steel plates by Sagamihara Works of Nippon Metal Industry Co., Ltd.

With regard to hot rolling equipment, a slab sizing press has been installed at Kashima Steel Works of Sumitomo Metal Industries, Ltd. and an edge heater at the entry side of finishing mill at Hirohata Works of Nippon Steel Corp. In technological aspects, techniques that have been developed include: manufacturing of hot rolled heavy plate of 70 and $80 \mathrm{kgf} / \mathrm{mm}^{2}$ for high workability structural purposes by Kashima Steel Works of Sumitomo Metal Industries, Ltd., development of a mill setting simulation program for a hot tandem mill by Kobe Steel, Ltd., and manufacturing techniques of nickel-clad steel plate by Sagamihara Works of Nippon Metal Industry Co., Ltd.

Regarding cold-rolling equipment, those that have been installed include: No. 3 cold rolling mill, No. 3 continuous annealing equipment, and laser dull working machine at Fukuyama Works of NKK Corp., No. 3 continuous annealing equipment at Chiba Works of Kawasaki Steel Corp., continuous coating line and reverse mill at Wakayama Steel Works of Sumitomo Metal Industries, Ltd., new-type batch annealing furnace, chrome plating equipment for rolling roll, and laser dull working machine at Kakogawa Works of Kobe Stcel, Ltd., and AP line and SL line for thin sheets at Itabashi Works of Nippon Metal Industry Co., Ltd. Besides the above, the continuation of pickling and cold rolling equipment of Kimitsu Works, Nippon Steel Corp. was remodeled. Technologies that have been developed include: minute trimming techniques by Nippon Steel Corp. and thin-belt rolling techniques of wide ultra thin stainless steel by Hanshin Works of Kawasaki Steel Corp.

The equipment associated with surface treatment that have been installed include: damping steel plate line at Nagoya Works of Nippon Steel Corp., new continuous galvanizing line at Keihin Works, No. 4 electrogalvanizing line (CGL), and No. 2 universal coating line (UCL) at Fukuyama Works of NKK Corp., No. 2 electrolytic galvanizing line at Kashima Steel Works and No. 3 GGL at Wakayama Steel Works of Sumitomo Metal Industries, Ltd., damping steel coil manufacturing equipment at Kakogawa Works of Kobe Steel, Ltd., and bright annealing (BA) furnace at Nippon Stainless Steel Co., Ltd.

Techniques that have been developed are: oil film thickness controlling by high speed ellipsometer by
NKK Corp., multi-layer thin film coating techniques by Nippon Steel Corp., and thin film clear-type organic composite steel sheet techniques by Sumitomo Metal Industries, Ltd.

\subsection{Instrumentation and Control}

New control and management technologies by the adoption of knowledge engineering in the iron and steel industry have in succession been introduced to various areas this year as well.

Technologies that have continuously been introduced to blast furnaces of various companies are: blast furnace operation control system provided with an action function by means of artificial intelligence (A.I.) such as furnace heat control based on the system of predict-prevention (go-stop system) of abnormal blast furnace conditions (No. 4 BF of Mizushima Works, Kawasaki Steel Corp.); medium-long-term furnace condition diagnosis and short-term furnace condition diagnosis systems that predict the causes of blast furnace abnormality (This has entered on the tests for practical use at No. I BF of Kashima Steel Works, Sumitomo Metal Industries, Ltd. since October, 1988.), and furnace condition diagnosis expert system for stabilization of blast furnace operation (No. $1 \mathrm{BF}$ at Kakogawa Works of Kobe Steel, Ltd.).

To cope with the requirements of small volume production with variety in sizes and grades due to the diversification of user needs, production scheduling and process management systems in which A.I. is adopted have also been developed. As outcomes of this development, worthy of mention are: automatic preparation system of operation scheduling for the steelmaking process of [converter]-[ladle refining process]-[continuous casting] (Keihin Works, NKK Corp.) and new production scheduling system (Hirohata Works, Nippon Steel Corp.).

Systems that have been developed in various steelworks include quantification of maintenance information for equipment diagnosis and equipment control, and systematization for improvement of the judgement of personnel in charge of maintenance (Oita Works, Nippon Steel Corp.; Chiba Works, Kawasaki Steel Corp.).

Development of measuring instruments in the instrumentation sector and development and systematization of measuring instruments for the improvement of measurement and control techniques in the rolling sector have been vigorously carried out. Measuring systems that have been introduced and put to practice use in various companies include: measurement of cracks in coke oven wall (Sumitomo Metal Industries, Ltd.), Si rapid analyzer to be used for desiliconization at the cast house (Fukuyama Works, NKK Corp.), probes for measurement of burden-layer thickness-distribution in a blast furnace and tuyere close probe (Chiba Works, Kawasaki Steel Corp.), a new type hot leveler for plate, oil film thickness control by a high-speed ellipsometer in the electrolytic tinning line (NKK Corp.), sheet thickness control system for the cold tandem mill and cold reverse mill (Kakogawa Works, Kobe Steel, Ltd.), proximity gamma-ray 
thickness gage for plate finishing mill (Mizushima Works, Kawasaki Steel Corp.).

\section{Technology Export and Import}

The growth of Japanese economy after the oil crises had already reached its peak in June 1985 prior to the G5 Plaza Mutual Agreement in September, 1985. With this as a turning point, the economy took a sharp downturn due to the high value of the Yen. The business, however, hitting bottom in November, 1986 , turned upwards at an unexpectedly rapid pace. The development of the business recovery this time is of a domestic-demand-led type supported by individual consumption and housing investment. As the marginal profits from the high yen filters through prices, the import structure principally consisting of raw material dealing has been greatly shifting to that of a type of horizontal division of work centered around final products. The expansion of the import of such products and the globarization of Japanese enterprise as seen in their overseas-shift urge the transformation of the industry and trade structure into that of an international cooperation type. This move is now exerting a direct influence on steelmaking companies in Japan.

According to statistics of the Japanese Government, the balance of technological know-how trade with the external world has turned into export surplus since 1974 F.Y., and still is maintaining such situation at present time. As shown in Fig. 3, technology exports in 1986 F.Y. reached 21.5 billion yen in amount receivable. This means 15.8 billion yen surplus compared with 5.7 billion yen paid for the import. Although the condition of export surplus still continued in 1986 F.Y., the receipts have been declining following the peak reached in $1983 \mathrm{~F} . \mathrm{Y}$. This tendency is attributed to the technology export to Asia which has been continuing to decrease since its peak attained in 1984 F.Y.

As regards the contents of recent technology export, what is actually required from the world, whether in- dustrialized or developing, is a comprehensive technical assistance including feasibility study, operational guidance, and planning of integrated rationalization project.

The results of the survey made by ISIJ on the contents of these technological export and import in the past 12 months are given in Tables 6 and 7 . The number of export cases this year is 215 , decreased by 86 cases under last year. Of these cases, 79 cases ( 30 under last year) were for North America district, 45 cases (38 under last year) for Europe district, 18 cases (18 under last year) for East Asia, the reduction in the exports to Europe and the USA being extremely conspicuous.

From the standpoint of technological category, the export still includes a large proportion of technologies associated with the internationally competitive fields in the steel industry of Japan, such as stcel pipe and tube manufacture, sheet manufacture, and surface treatment. In spite of the decreasing tendency of overall exports, comprehensive technological competency of Japanese stcel industry has been called for as seen from the export results; i.e., 3 general operations guidance ( 0 in last year), 9 overall feasibility studies of steelworks (7 last year), and 3 planning and designs of steelworks construction (4 last year).

Technology import has run with 17 cases this year, being at the same level as last year which ended in 15 cases.

\section{Energy Consumption of the Steel Industry}

The energy consumption in the steel industry in 1987 F.Y. resulted in an amount equivalent to 68.87 million $\mathrm{t}$ coal, about $6 \%$ above its last-year level reffecting an increase in steel production (65 million $t$ in 1986 F.Y.). When this is viewed from the specific consumption per ton of crude steel, it becomes 4.66 million $\mathrm{kcal} / \mathrm{t}$, being at about the same level as that last year $(4.65 \mathrm{kcal} / \mathrm{t}$ in $1986 \mathrm{~F} . \mathrm{Y}$.).

By the types of energy, $80.6 \%$ came from coal and its derivatives $(80.4 \%$ in 1986 F.Y.), $6.2 \%$ from oil
Fig. 3.

Balance of technology trade of steel industry. Source:

"Report on the survey of the Research and Development", Statistics Bureau, Management and Coordination Agency, The Japanese Government, (1982-1986).

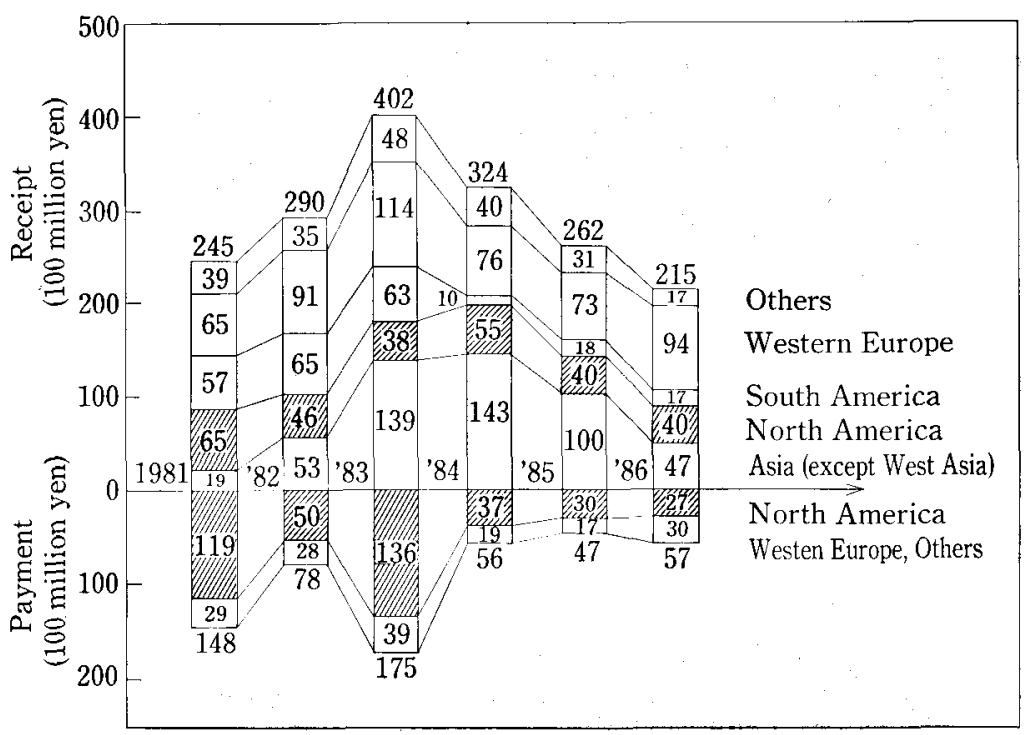


ISIJ International, Vol. 29 (1989), No. 4

Table 6. Contents of technology exports. (September, 1987-August, 1988)

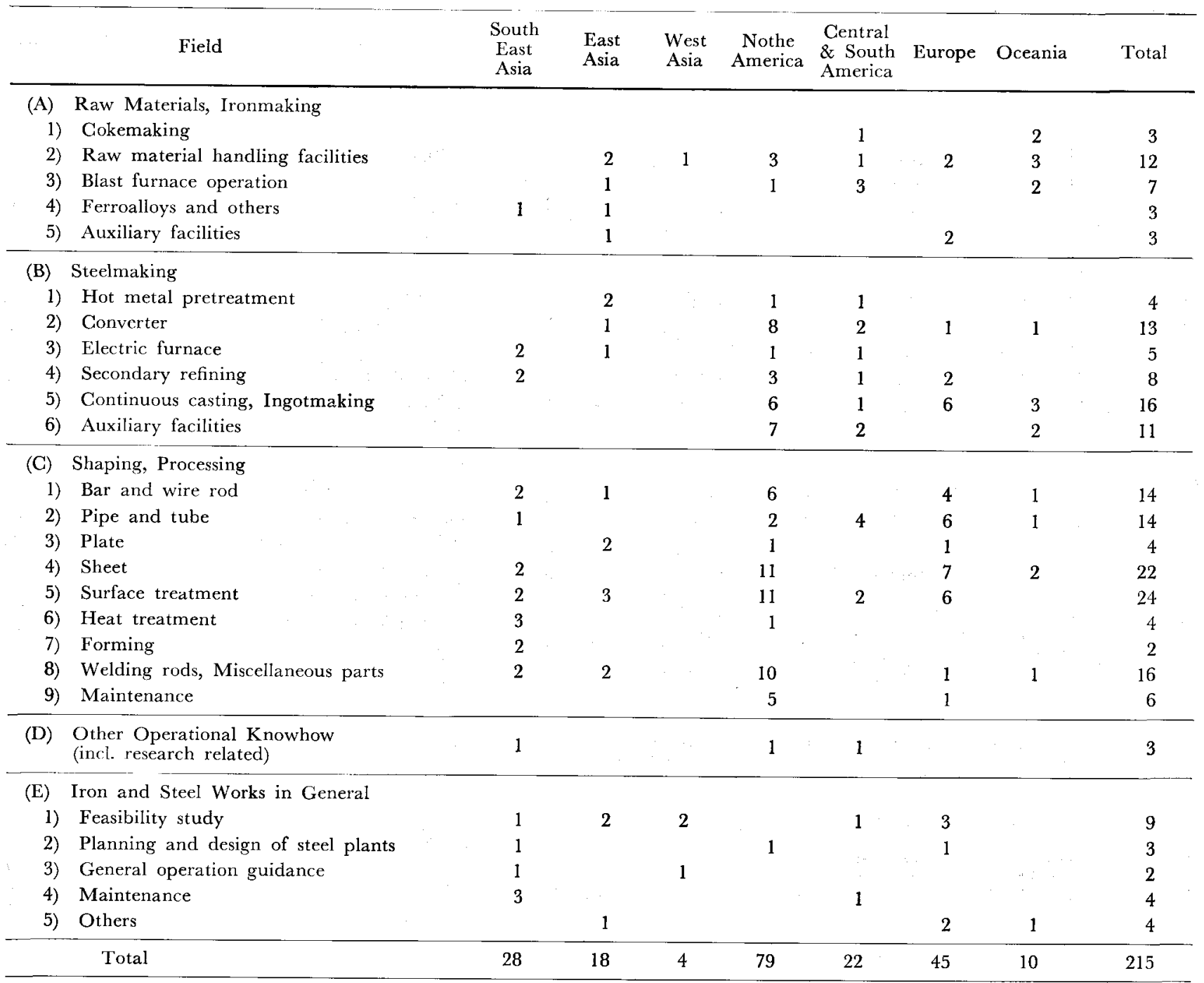

Goverage: 45 member companies of ISIJ

Country names in areas:

South East Asia: The Philippines, Malaysia, Indonesia, Singapore, Thailand

East Asia: China, Taiwan

West Asia : India, Pakistan, Srilanka

North America: U.S.A., Canada

Central \& South America: Brazil, Peru, Chile, Venezuela, Mexico, Jamaica

Europe : $\quad$ U.K., France, Italy, Spain, The Netherlands, Sweden, Finland, Norway, Portugal

Oceania : Australia, New Zealand

base fuels ( $6.5 \%$ in 1986 F.Y.), and $13.2 \%$ from purchased power ( $13.1 \%$ in 1986 F.Y.); thus, coalderivatives trending upwards, while petroleum-derivatives downward. This is ascribed to the fact that coal utilization is being promoted by integrated iron and steel manufacturers where crude steel production accounts for $70 \%$ of the total production.

The energy consumption of major energy consuming processes in iron and steelmaking was as follows: $73.1 \%$ in ironmaking ( $73.5 \%$ in 1986 F.Y.), $2.3 \%$ steelmaking $(2.3 \%), 15.0 \%$ in rolling $(14.7 \%)$, and $9.6 \%$ in others $(9.5 \%)$, which were the same level with the previous year.

\section{Expenditure for Research and Development}

Steel companies have, this year as well, been aggressively pushing forward with the development of technology to further take the lead in terms of cost, quality, and grade in the worldwide market. The basic financial figures associated with steel industry reported in the statistical survey of research and development by the Japanese Government for 1987 F.Y. are shown in Table 8 . The ratio of the internal research expenditure to the total sales in 1986 was $2.5 \%$, a rise of $6.1 \%$ over the previous year, and the number of employees entirely devoted to research and development was 197 per 10000 employees, an increase of $11.3 \%$ over the previous year. The total corporate research expenditure consisted of 255.2 billion yen for own 
Table 7. Contents of technology imports. (September, 1987-August, 1988)

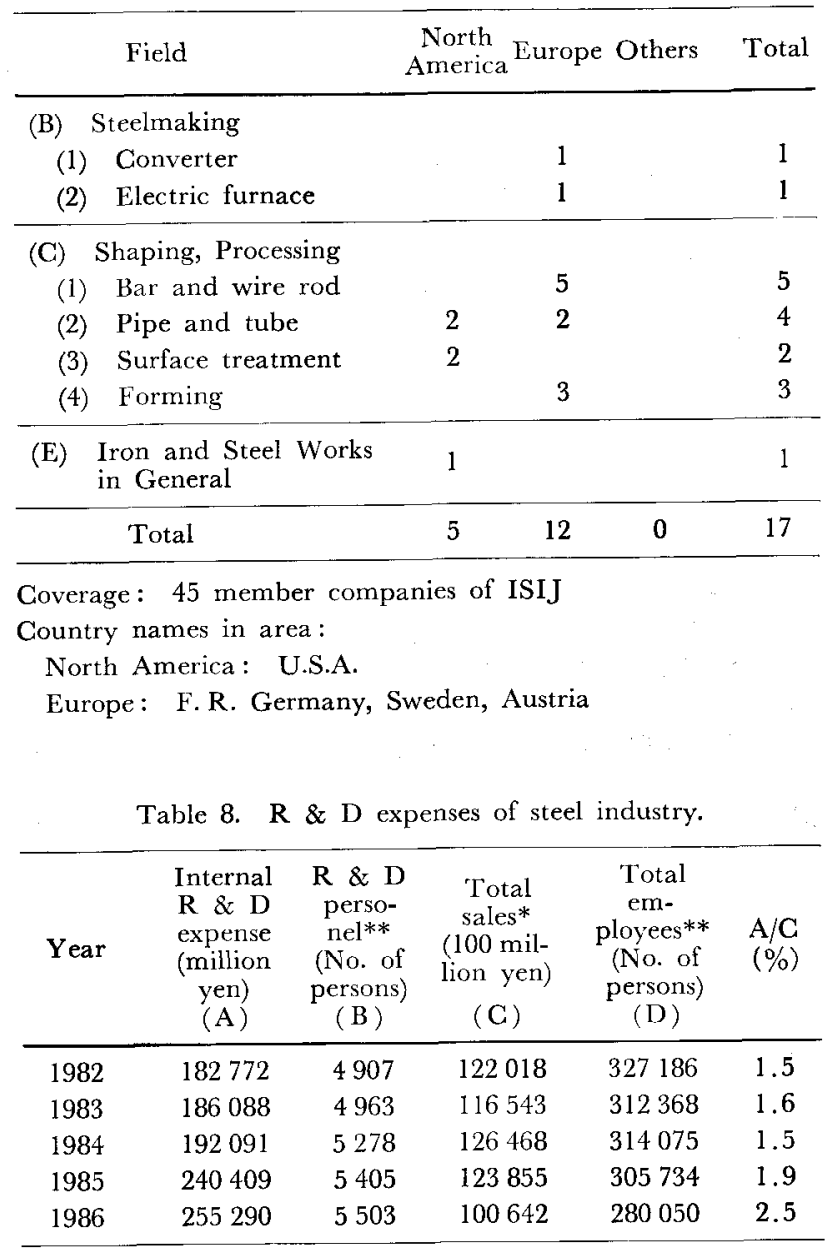

* According to statistics on $\mathrm{R} \& \mathrm{D}$ expenses.

** Number of persons as of the end of fiscal year.

Source: "Report on the Survey of the Research and Development", Statistics Bureau, Management and Coordination Agency, The Japanese Government, (1987).

laboratories (240.4 billion yen in 1986 F.Y.) and 5.51 billion yen ( 5.23 billion yen in 1986 F.Y.) in entrusting to outside establishments. The latter was $8.6 \%$ for national and municipal research laboratories $(7.0 \%)$, $3.2 \%$ for special corporate laboratories $(1.7 \%), 70.4$ $\%$ for private organizations $(75.3 \%)$, and $17.8 \%$ for overseas $(16.0 \%)$. The internal research expenditure per employee entirely devoted to research and development in 1987 was 46.39 million yen including personnel cost (44.48 million yen in 1986 F.Y.).

\section{Technical Movement of Galvanized Steel Sheets}

Zinc is comparatively inexpensive, excellent in corrosion resistivity, and possessed of sacrificial corrosion protection function even when the steel substrate is exposed. Due to these properties, zinc has long been widely used for corrosion protection of steels. In response to the needs of diversification in recent years, new products even in the area of galvanized steel sheets have successively been developed, and the ra- tionalization of the manufacturing process effected; thereby, their demand has been widely expanding.

\subsection{Hot-dip Galvanizing Method}

Hot-dip galvanized steel sheets are generally thick in plated metal, the hardness of sheets becomes slightly higher than electrogalvanized sheets because of the thermal aging effect of the process on condition that both sheet materials are the same. The former, however, is predominant to the latter in quality as well as in cost where high corrosion resistance is required. Technical development has expanded the manufacturing scope of the products from those for extra deep drawing to high strength sheets for fabrication, the demand being suddenly swelling around the usage for automobiles.

Of all, galvannealed steel sheets whose surface has undergone heating for alloying of plated layers show outstanding increase in elongation. Galvannealed steel sheets are excellent in adhesion of coated layer and weldability compared with galvanized steel sheets which do not permit alloying. With these sheets, technical innovation such as automatic control techniques of alloying as a quality stabilization technology has been being effected.

One-side galvanized steel sheets are adaptable for the use wherc required external steel surface favorable in coating ability and the internal surface for corrosion resistant with zinc, being applied to the outer panels of automobile. The mainstream of manufacturing methods of one-side galvanizing include:

1) masking method in which stop-off material is coated on the side of non-plated surface, and

2) electromagnetic pump method and roll coating method in which only one side is coated from the beginning.

The manufacturing methods of minimized-spangle products, in which zinc crystals have been brought into fine ones by controlling, include:

1) making the bath $\mathrm{Pb}$-less,

2) spraying of chemical products, and

3) powder zinc spraying method (Herty method).

In recent years, Herty method is attracting attention for its merit in homogeneous treatability. In treating galvannealed steel sheets, the maximum line speed is limited to about $150 \mathrm{~m} / \mathrm{min}$ because of less weight of plated metal and the restriction of the alloying furnace. Where regular-spangle and minimized-spangle sheets are treated, the limit of the maximum speed reaches as fast as $200 \mathrm{~m} / \mathrm{min}$ by the incorporation of a gas-wiping-method. In order to realize high speed treatment, techniques have been developed, such as

1) setting the wiping nozzles at an acute angle,

2) nitrogen gas sealing for reduction of dross generation, and

3) oscillation prevention of strip by the application of air cushion bearings and magnets.

Moreover, to cope with increasing line speed and high temperature annealing of sheets for fabrication purpose, a vertical type annealing furnace allowing for a longer pass line and smaller building area has been developed and brought on stream. This vertical an- 
nealing furnace is also recognized as a furnace having merits in improving quality by the prevention of pick up caused by in-furnace rolls and in improving strip shape, being expected to be widespread hereafter.

In the area of aftertreatment, numerous product developments have been taking place, such as:

1) high corrosion resistant chromate treated steel sheets,

2) organic polymer coated steel sheets,

3) high lubricant coated steel sheets,

4) blacking steel sheets, and

5) high solderability treated steel sheets.

The performances have come to be targeted not only for improved corrosion resistance but also for diversified functions.

As of September, 1988, 37 continuous galvanizing lines are in operation in Japan, of which, 9 lines are being used in combination for plating of aluminumzinc alloys such as of a $5 \% \mathrm{Al}-\mathrm{Zn}$ system or of a $55 \%$ Al--Zn system. Great hopes are entertained of these products for future growth as materials not only for use in bare condition by depending on their excellent corrosion resistance but also for use for coating.

\subsection{Electrogalvanizing}

Electrogalvanized steel sheets have so far been used for interior uses such as home electric appliances and steel furniture because of their beautiful looking surface with less plated metal amount and favorable workability. Meanwhile, since the time these products came to be adopted in automobiles, thick-platingoriented need has come to be highlighted. However, thick plated metal layer exerts an adverse influence on workability and weldability, which promoted the development of steel sheets plated with a zinc-system alloy which are excellent in corrosion resistance and film adhesion even with a thinly plated film, leading to an achievement of a marked advancement.

Major alloy-plated steel sheets include those plated with alloy systems of (1) $\mathrm{Zn}-\mathrm{Co}$, (2) $\mathrm{Zn}-\mathrm{Ni}$, and (3) $\mathrm{Zn}-\mathrm{Fe}$. The $\mathrm{Zn}-\mathrm{Fe}$ system alloy has been developed with an aim to effecting an excellent corrosion resistance after coating. The requirements of one material for many functions such as water-resistant adhesion of coated film, coating workmanship, etc. have pushed forward the development of various kinds of (4) multi-layer plating.

The key to the manufacturing technology in an electrogalvanizing line (EGL) is how much the current density can be raised with the voltage suppressed. To attain this, various contrivances have been made in the method of flowing plating electrolyte in the cell, enabling a current density of $200 \mathrm{~A} / \mathrm{dm}^{2}$ or more at the present time. Of the 20 EGLs presently in operation in Japan, 10 lines are being operated at a line speed of $150 \mathrm{~m} / \mathrm{min}$ or more.

New models of plating cell as of a horizontal type include (1) jet cell, (2) anode center injection cell (ACIG), and (3) liquid cushion cell (LCG). These methods all use insoluble anodes on the premise of using sulphuric acid bathing, dispensing with changing over operation and allowing shortening of the dis- tance between the anode and the cathode. On the other hand, (4) cells of a radial type, where a strip is immersed in the plating electrolyte with the strip wound around a large diameter conductor roll, have features of easiness of employing soluble anodes and adaptability to one-side plating. In this method, no catenary of strip as inevitable in the case of a horizontal cell is present. In addition to the above, (5) a vertical cell permitting a uniform plating over both sides of the strip has also been put to practical use.

In electrogalvanizing in which the control of plating electrolyte is important, automation and systematization of analysis have been rapidly advancing. In this operation, there are involved many essential items such as supply of zinc ions in the case of employing insoluble anodes, use of filters for sludge removal, cooling of electrolyte, and prevention of electrolyte mixing in the case of alloy plating. For all of these, various contrivances have been made.

Of late, continuous vacuum deposition zinc plating equipment which has gone into the line on production basis has been drawing attention. There is also a new move to incorporating coating equipment into the electrogalvanizing line and electrogalvanizing to the hot-dip galvanizing line. It is predicted that the necessity of positive application of a technology to the different field and complexing of technology will be increasingly needed hereafter.

\section{Research Activities of ISIJ}

\subsection{Application Technology}

\section{Ironmaking Committee}

The Committee held 2 meetings in May (72th) and in October (73th), 1988, on the common themes "Labor-saving in Ironmaking Process" and "Quality Control of Blast Furnace Burden", respectively, and lectures were delivered on the themes "Analysis of Blast Furnace Hearth Phenomena" by Kure Laboratory of Nisshin Steel Co., Ltd. and "Operational Progress of Multi Purpose Injection (MPI)" by Chiba Works of Kawasaki Steel Corp.

\section{Coke Committee}

The 36th meeting in May and the 37th meeting in November, 1988 were held and on the common themes " Recent Operation of Coke Plant" and "The Present Condition and Future of Labor-saving in Coke Plant".

\section{Steelmaking Committee}

The 98th meeting was held in March, 1988 on the main theme "Heat-addition Technology in Refining Process" for heat compensation for alleviation of converter and electric furnace energy loads, and the 99th meeting in September on " Technology for Reducing Sheet Surface Defects Cause".

\section{Electric Furnace Committee}

At the 31 st meeting in May, 1988, report and discussion was held on the common theme "Productivity Improvement in Steelmaking Plant" and at the 32nd meeting in October, 1988 on "Improvement of Furnace Body Refractories of Arc Furnace". At this meeting in October, a special lecture was given by 
Professor Kiuchi, The University of Tokyo, on "New Material Development by Mashy-state Metal Forming ".

\section{Special Steel Committee}

Report and discussion were held at the 84th meeting in March, 1988 on the common theme " Reduction of Impurity Elements in Super Alloys, Heat-resisting Steels, Stainless Steels and Other High Alloy Steels and Trace Element Addition Technology" and at the 85th meeting in October, 1988 on "Recent Improvement in Cost and Quality Made on Refractories". At this meeting in October, a special lecture was delivered by Assistant Professor Yamaguchi, Nagoya Institute of Technology on "What Refractories Really Should Be".

\section{Blooming and Slabbing Subcommittee of Steel Plates} and Sheets Committee

A joint meeting was held in May, 1988 by the Blooming Subcommittee and the Slabbing Subcommittee, where discussion was made on the common theme "Manufacturing Technology of Special Steel Semiproducts".

7. Plates Subcommittee of Steel Plates and Sheets Committee

Discussion was held on "Mill Operation Condition and Situation of Countermeasure for Recent User Requirements" at the 65th meeting in May and the 66th meeting in November, 1988.

8. Hot Strip Subcommittee of Steel Plates and Sheets Committee

The 48th meeting in May and the 49th meeting in December, 1988 were held on the common theme "Equipment Maintenance Viewed from the Angle of Product Quality".

\section{Cold Strip Subcommittee of Steel Plates and Sheets Committee}

The 47th meeting in June and 48th meeting in December, 1988 were held. Their respective common themes were "Improvement of Quality and Yield", and "Rolls for Rolling".

\section{Galvanized Steel Sheets Committee}

The 5 th meeting in January and the 6 th meeting in August, 1988 were held. At these 2 meetings, discussion was respectively held on the common themes "Improvement and Advancement of Quality Warranty System", and "Improvement of Production Efficiency".

\section{Sections and Wire Rods Committee}

The 3 Subcommittees under this Committee held their meetings twice.

(1) Large Section Subcommittee

Discussion was held on "Operation Data and Topics" at the 47th meeting in June, 1988 and on "Rationalization of Personnel" at the 48th meeting in November, 1988.

(2) Medium and Small Sections Subcommittee

Discussion was held on "Mill Operation Conditions" and free research themes. Besides the above, A Group (Ordinary Carbon Steel) had discussion in May (64th) and in November (65th), 1988, respectively on "Accessories of Rolling Mills (Including
Spare Parts Control and Rationalization)" and " Reduction of Manufacturing Cost (Including Energysaving)". The B Group (Special Steel), at the same time, held discussion respectively on "Countermeasures for Improvement of Efficiency and Production Rate in Rolling Mills (Including Countermeasures for Improvement of Precision Rolled Bar Manufacturing)" and "Quality Assurance System".

Also a special lecture was given on "Recent Control System of Section Mill" at the spring meeting.

(3) Wire Rods Subcommittee

Besides the discussion on "Mill Operation Conditions" and free research themes, discussion was held in June (65th) and in November (66th), 1988, respectively on "Maintenance System of Rolling Mills" and "Roll Control and Countermeasures for the Specific Consumption Improvement".

The themes of the theme study for foreman for the 65 th and the 66 th meetings were respectively " Role of Foreman on Promoting Personnel Rationalization and Its Problems" and "Safety Measures on Promoting Personnel Rationalization".

12. Steel Pipes and Tubes Committee

At the 50th meeting held in June, 1988, discussion was held on the theme on "Recent Expansion of Available Size Range and Grades", and at the 5lst meeting in October, a lecture was given on "Kansai International Air Port Project and Its Present Condition" and at the same time a commemorative lecture for the 25th anniversary of the Committee was delivered on "Review of Steel Pipes and Tubes Committee and Its Memory".

\section{Rolling Theory Committee}

The Committee held meetings in March (87th) and in September (88th), 1988. Discussion was held principally on subjects relative to sections, wire rods, sheets, and electric resistant welded pipes and tubes.

\section{Heat Economy Technology Committee}

The achievement reached by the Cooling Technology Subcommittee set up in April, 1986 was published as a report titled " Cooling Technology in Iron and Steel Manufacturing Process", by ISIJ in September, 1988.

As a theme of the Subcommittee from April, 1988, "Electric Heating" was selected.

\section{Refractory Committee}

Besides free themes, discussion was held on "Hot Metal Pretreatment" and "Mechanization of Refractory Laying Work" at the 43rd meeting in June, 1988 and on "Trough Materials, Mud Materials, Equipment Diagnosis, and Mechanization" at the 44th meeting in November, 1988.

Also a special lecture was given at the 43rd meeting on "Recent Condition of Zircon" by Mr. Murai, Iwatani International Corp.

The materials contributed and presented at the 3rd West Germany-Japan Technical Exchange Meeting on Refractory (November, 1987) were summarized and published in English text (June, 1988), whose title is Advanced Recent Technology of Refractories for Steel Industry in Japan and the Federal Republic of Germany-The Third ISIJ and VDEh Technical Exchange 


\section{Meeting on Refractories-".}

\section{Instrumentation and Control Committee}

At the 2 meetings of the 97th in April and 98th in October, 1988, discussion was held on the 8 fields of ironmaking, steelmaking, rolling, energy, productssemiproducts inspection, maintenance technology, new and improved technique, etc.

Many reports related to automation, labor-saving, and systematization for process continuation were presented.

\section{Quality Control Committee}

The Committee held 2 meetings in July (58th) and in December (59th), 1988. Discussion was held respectively on "Incipient Control of New Products and New Equipment" and "Present Condition and Problems Related to Surface Quality Guarantee of Steel Products for Automobile and Household Electric Appliances".

Non-destructive Inspection Subcommittee and Mechanical Testing Subcommittee of this Committee held two meetings each for discussion.

\section{Transportation Committee}

Railless Transportation in the Steel Plants Study Subcommittee was set up in January, 1988, and conducted questionnaire and hearing survey as to the change of transportation in the compound of steel industry and the present condition of the equipment and control system, discussing on the future image of transportation in such industry.

\section{Investigation Committee}

The results of the investigation on the research theme for this fiscal year of "Technological Capability and Development of Overseas Steel Industry" have been put together and reported at the 15 th meeting held in March, 1988.

\section{Iron and Steel Analysis Committee}

Five persons concerned with steel analysis from JERNKONTORET (Iron and Steel Institute of Sweden) visited to Japan in October, 1987, making a technical exchange with persons concerned with analysis from Japanese steelmaking companies.

Instrumental Analysis Subcommittee is now putting in order the activity condition as to the Confirmation for its Accuracy of Quantitative Analysis of Small Amount Elements by Emission Spectral Analysis.

To amend the Japan Industrial Standard (JIS) of Fluorescent X-ray Analysis Method of Iron Ore, joint experiments will be conducted on the common specimens. As a new research theme, the amendment of various specifications are scheduled; i.e.,

1) method of emission spectral analysis of minute amount of carbon $(<100 \mathrm{ppm})$,

2) fluorescent $X$-ray analysis of blast furnace slag,

3) fluorescent $X$-ray analysis of titanium alloys,

4) emission spectral analysis of iron and steel, and

5) fluorescent X-ray analysis of iron and steel.

The Subcommittee on Study of Analysis of Separating Phases in Steel conducted a study on chemical extractive separation analysis method of fine precipitation phase of intermetallic compounds, and observed the morphology of the separations, identifying the condition of extraction and separation.

At the meetings of Chemical Analysis Subcommittee held in May and November, 1988, discussion was made by the Phosphorous Analysis WG on the countermeasures for tungsten-bearing steels, and by the Nb-Ta WG on the quantitative analysis method of tantalum. The JIS amendment draft of "Quantitative Analysis of Boron in Iron and Steel " is now under preparation by Boron Analysis WG. From this fiscal year, the new working group has started its activities in the study on the frameless atomic absorption spectrochemical analysis.

As new themes, studies have been conducted on the " Cr-V Potential Difference Titration Method (Normalization in JIS)", "Quantitative Analysis of As (Extension of Lower Limit)", and "JIS Amendment for Iron Ore".

At the Surface Analysis Subcommittee, four meetings being held, the following six joint studies have been carried on:

1) ion spattering,

2) AES quantitative analysis,

3) AES condition analysis,

4) XPS quantitative analysis,

5) XPS condition analysis, and

6) GDS.

The above studies will successively be brought to completion and contributed to "Tetsu-to-Hagané" for the next fiscal year.

In addition to the above, a joint study on analysis of surface contaminants of silicon wafer was newly set about.

21. Iron and Steelmaking Plant Engineering Subcommittee, Plant Engineering Committee

At the meeting of the Subcommittee held in two times in May (38th) and in November (39th), 1988, discussion was held on the common themes "Automated Equipment of Continuous Casting" and "Blast Furnace Relining", respectively.

\section{Rolling Mill Engineering Subcommittee, Plant Engi- neering Committee}

At the meeting of the Subcommittee in May (38th) and that in November (39th), 1988, study was made respectively on "Maintenance Condition of Major Equipment for Improvement of Operation Rate and Quality" and "Trend of Equipment Diagnosis Engineering and Its Application",

23. Electric Facilities Engineering Subcommittee, Plant Engineering Committee

At the meetings in June (24th) and December (25th), 1988, discussion was made respectively on "Problems and Future Subjects on the Use of AG Variable Speed Device", and "Present Condition of Material Flow Automation and Study of its Future Trend".

\subsection{Basic Research}

7.2.1. Basic Research Association on Specific Subjects

1. Committee on Material Evaluation by Image Analysis This Committee (twice) and Subcommittees (three times) on Crystal Grain Size, Segregation-Inclusions, 
and Fracture Surface made studies on the development of the standardization and program principally of image analysis.

At the 115th ISIJ Meeting in April, an interim report was presented. (see Current Advances in Materials and Processes, 1 (1988), No. 2, 541-548)

In the coming fiscal year, the final activity report including data sheets cdition will be published.

\section{Committee on Electromagnetic Metallurgy}

The Committee made reports on study and research results on the application of electromagnetic force to metallurgical processes, especially the reports being focussed on a cold crucible effective as a technique to melt high-melting-point metals, reactive metals, and oxides, and filmy flow forming function by a DC magnetic field.

3. Committee on Design and Control Interphase and Crystal Boundary in Steels

This fiscal year, discussion was made on the results of observation under a high-resolution electron microscope as to the migration phenomena of nano-crystal palladium and hard-worked fine crystal tin on a phase interface and grain boundary at high temperatures.

4. Committee on Coal Carbonization Reaction Mechanism

At the meeting of the Committee held in October 1988 (5th), discussion was conducted.

This Committee continued its activities in 6 Research Groups. The research themes were:

1) interfacc chemistry of coal,

2) analysis of carbonization reaction (thermo chemistry),

3) analysis of carbonization reaction (material transfer),

4) chemistry of coal fusion,

5) by-product production mechanism, and

6) chemistry of semi-coke carbonization.

5. Committee on Stress Corrosion of Steels

Elucidation and stress analysis of corrosion morphology under stress were made to rationally evaluate the adaptability of steels used in a harsh corrosion environment in which hydrogen sulfides are present, such as sour environment and plant environment. The Committee started its activity from May, 1988 with the aim of developing a rational setting method of evaluation methods and evaluation conditions.

6. Committee on Reliability Evaluation of Structural Materials

This Committee is set up by succeeding researches that were supported by the special coordination funds of the Science and Technology Agency of the Japanese Government. This fiscal year, the Committee held a meeting once, deciding to continue research activities mostly on the establishment of real scale experiments, i.e.,

1) establishment of evaluation techniques of high temperature damage, and

2) establishment of evaluation techniques of environmental effect on material strength.

These researches were started by the respective Working Group.
7.2.2. Joint Society on Iron and Steel Basic Research

1. Committee on Rapid Solidification of Iron and Steel

The Committee held 4 meetings in 1988, having discussion on the research results. The Committee, furthermore, is now compiling a report to mark the completion of the activities, "Activity Report", "Glossary of Rapid Solidification", and "Photo Collection of Rapid Solidification ".

\section{Committee on High Purity Steel}

The Committce held 3 meetings, conducting research works. The committee is now putting the research results together into a report "Progress on High Purity Steel Research".

\section{Committee of Ultrafine-grain Steels}

The Committee conducted experiments as to the method in which the grain size of steels are refined into sizes less than several microns by means of processing and heat treatment, rapid solidification, and powder metallurgy, holding discussion on the research in which the method and mechanism of ultrarefining of grains were elucidated.

4. Committee on Interfacial Transport Phenomena

The Committee held 2 mectings in June (6th) and in November (7th), 1988, making an interim report.

The scope of the researches is as follows:

1) elucidation of bubbling phenomena mainly in the slag phase

2) elucidation of volumetric coefficient in gas-liquid or liquid-liquid refining reactions

3) elucidation of the role of Marangoni phenomenon in the refining process

4) development of new measurement method for interfacial transport phenomena.

5. Committee on Iron-base Composite Materials

The Committee held 2 meetings in August (1st) and November (2nd), 1988. This Committee is one which has been newly set up this fiscal year, planning to conduct researches to clucidate processing technology and interfacial conditions around $\mathrm{Fe}-\mathrm{Ti}$ composite materials and others.

\subsubsection{Other Committees}

\section{Sensor Technology Subcommittee}

The Committee completed and published the final report titled Present Condition and the Future of Sensors for Iron and Steel Industry.

\section{High Temperature Strength Research Committee}

Under this Committee, 4 Subcommittees are presently at work.

The Notch Effect Test Subcommittee conducted a joint experiment titled "Determination of Crack Initiation Gycle by DC Potential Method in High Temperature-Low Gycle Fatigue of Notched Materials (a Tentative Recommendation of Test Method by ISIJ) ", now preparing such report.

The High Temperature Embrittlement Subcommittee is now putting in order the research results of "Relation between Room Temperature Embrittlement and Physical Properties in Heat Resisting Steels Aged at Elevated Temperature under Creep Loading ". As the theme for the next term, the Commit- 
tee is planning to conduct joint experiments on " $\mathrm{Re}$ search on Mechanical and Physical Properties of Long-term Used Cr-Mo Steels".

The High Temperature Thermal Fatigue Test Subcommittee conducted joint experiments by the Working Group on the Guide Line of VAMAS Low Cycle Fatigue Testing, now being preparing its report.

\section{Committee on High-strength Line Pipe}

The Subcommittee on Hydrogen Induced Cracking (HIG) presented the results of HIG tests, which have so far been conducted, at the CORROSION/88 International Conference (the USA) in March, 1988, proposing a new testing solution of ISIJ. Burst Test Subcommittee conducted reproducibility experiments by small-scale testing on Pressure Reversals (reduction of withstanding pressure of a pipe line caused by ductile crack propagation at the time of field pressure testing).

\section{Titanium Materials Committee}

The Committee held 4 meetings (the 8 th to the 11 th), giving research reports and a special lecture mainly on themes "Processing and Welding of Titanium Materials", "Intermetallic Compound", "Heat-resistance of Titanium Alloys", etc.

\section{Material Research Committee}

The Committee held the 65th and 66th meetings, giving a research report on the common theme "Phase Transformation Behavior of Steels".

6. Research Committee on Mechanical Properties of Structural Steel

The Committee, holding the 5 th and 6 th meetings, reported the research results, and concluded its duty with the 6th meeting. In September, 1988, Chairman Tsutomu Kato (The University of Tokyo), Committee Hirobumi Aoki (Yokohama National University), Committee Yasuyuki Yamanouchi (Building Research Institute, Min. of Construction) presented themselves at the International Conference of Reunion Int. de Labs. d'Essais et de Rech. sur les Mater. et les Construc. (RILEM) in Paris.

\section{International Iron and Steel Technology Committee}

At the meetings held in June and November, 1988, Chairman Dr. T. Kohno gave a report on the processing of the 20th TECHCO Committee held in Brussels in April, 1988 and the study results of the Action Plan of TECHCO-Steering Meeting held in Seoul in October, 1988, respectively.

8. Subcommittee on Materials for Marine and Offshore Services

To promote offshore applications and development hereafter, necessary are organic cooperation of the existing engineering fields closely related to ocean engineering or the development of the interdiscipline between the existing engineering fields. For this reason, seven scientific and technological institutes and societies set up, in close cooperation, Ocean Engineering Liaison Conference in January, 1988. ISIJ has been assigned to cooperate with the Liaison Committee mainly from the viewpoint of steel materials, establishing "Sub-Committee on Materials for Marine and Offshore Services " under the Research Planning Committee in January, 1988. The 1st Activity
Briefing Session of the Ocean Engineering Liaison Conference was held in June, 1988 on the theme "Expectation for Future Ocean Development and the Role of Each Engineering Field". This Committee presented a report on "Activities Associated with Ocean Development of the Iron and Steel Institute of Japan ".

\section{Japan Pressure Vessel Research Council}

The Material Committee of which ISIJ is in charge has almost completed the works of putting together the data of materials for laboratory-scale melting associated with "PWHT Characteristics of TMCPSteel" Phase I, and started the experiments on the Phase II (Mill-rolled products) at the task group meeting of the Committee on Pressure Vessel Steels. The Committee on Hydrogen Embrittlement is now conducting the joint research on $2 \frac{1}{4} \mathrm{Cr}-1$ Mo steel at the task group meetings of TG V and TG VI. At the Committee on Non-destructive Evaluation Materials for Pressurc Vessel Components Examination, as participating with the NDE of PISC III, the round robin tests of specimens with nozzles were conducted in cooperation with the Japan Power Engineering and Inspection Corporation.

\subsubsection{Public Invitation for Research Themes}

Continuing from last year, public invitation was made for research themes to universities, national and municipal research laboratories and steel company laboratories to promote the fundamental researches of science and technology associated with iron and steel, so that contribution to the development of new technology will be made and industry-academics cooperation will be further enhanced.

As a result of this year's invitation, 65 research themes were received.

These themes were classified into: 5 grants, the individual research of which is suitable to be entrusted to the proponent with the research expenses paid by ISIJ, 40 themes which are suitable to be left to the direct consultation between the proponent and a research organization willing to cooperate, 19 themes which research are to be entrusted to universities from companies, and one theme which is suitable to be subjected for discussion to the Basic Research Association on Specific Subjects of ISIJ and promoted as a joint study of universities, national and municipal research laboratories and steel companies.

\subsubsection{Survey on the Status Quo of Metallurgical Engineering Researches in Universities}

The metallurgical engineering researches (ranging over material properties, refining, chemistry, processing, and manufacturing including surface treatment and anti-corrosion) in universities have been surveyed, and the status quo of the activities of 22 subjects of study, 16 departments of 15 universities have been identified.

\subsubsection{Ishihara-Asada Research Fund Awarding}

As a result of the 17 th invitation, 15 applications were received, of which the fund has been awarded to 2 subjects related to refining, 3 to materials, and 3 
to others.

7.2.7. Executive Committee on Educational-visiting Party of Students

The Committee, with the consent of the 13 scientific institutes and societies, held students' visit for study (3rd) to steelworks and its laboratories at 12 places all over the country on March 23 to 25, 1988, in which 270 students have participated.
The Executive Committee is now preparing to hold the 4th Educational-visiting party in March, 1989.

\section{Acknowledgements}

The author wishes to express deep gratitude to The Iron and Steel Production Division, Ministry of International Trade and Industry, and to those of concerned ISIJ Secretariat who cooperated for the preparation of this manuscript. 